\title{
Distribution of Chrysoporthe Canker Pathogens on Eucalyptus and Syzygium spp. in Eastern and Southern Africa
}

G. Nakabonge, J. Roux, M. Gryzenhout, and M. J. Wingfield, Department of Microbiology and Plant Pathology, Tree Protection Cooperative Programme (TPCP), Forestry and Agricultural Biotechnology Institute (FABI), University of Pretoria, Pretoria, Republic of South Africa

\begin{abstract}
Nakabonge, G., Roux, J., Gryzenhout, M., and Wingfield, M. J. 2006. Distribution of Chrysoporthe canker pathogens on Eucalyptus and Syzygium spp. in eastern and southern Africa. Plant Dis. 90:734-740.

Chrysoporthe cubensis and C. austroafricana, collectively known as Cryphonectria cubensis in the past, are important canker pathogens of Eucalyptus spp. worldwide. Previous studies have suggested that Chrysoporthe austroafricana occurs only in South Africa, whereas C. cubensis occurs in Australia, Cameroon, Tanzania, Democratic Republic of Congo, Republic of Congo, Southeast Asia, and South, Central, and North America. In South Africa, C. austroafricana is a pathogen on nonnative Eucalyptus (Myrtaceae) and Tibouchina (Melastomataceae) spp., both residing in the order Myrtales. Recently, the fungus also has been found on native Syzygium cordatum trees in the country, leading to the hypothesis that it is native to Africa. In contrast, $C$. cubensis is thought to have been introduced into Africa and is known only on non-native Eucalyptus spp. and S. aromaticum (clove) in four countries. The aim of this study was to consider the distribution of Chrysoporthe spp. on non-native Eucalyptus spp. as well as on native Myrtales in southern and eastern Africa. Isolates were collected from as many trees as possible and characterized based on their morphology and DNA sequence data for two gene regions. Results show, for the first time, that $C$. cubensis occurs in Kenya, Malawi, and Mozambique on nonnative Eucalyptus spp. C. austroafricana was found for the first time in Mozambique, Malawi, and Zambia on non-native Eucalyptus spp. and native S. cordatum. The known distribution range of $C$. austroafricana within South Africa also was extended during these surveys.
\end{abstract}

Additional keywords: Cryphonectria, disease, forestry

Species of Chrysoporthe previously treated in the genus Cryphonectria (12) are important canker pathogens of Eucalyptus spp. grown in plantations in both tropical and subtropical areas worldwide. They have been reported in South and Central America $(2,15,16,32)$, Southeast Asia $(8,18,22,29)$, Australia $(6,23)$, North America $(15,22)$, and Africa $(10,18,27,28,40,42)$. The disease with which Chrysoporthe spp. are associated has been known as Cryphonectria canker in the past, and leads to the girdling of stems, wilting, and death of infected trees $(4,15,17,29)$. The cankers can occur at the bases of the stems or are found higher up on the trunks $(4,15,16,29)$. The disease caused by Chrysoporthe spp. has been managed successfully by breeding for disease-tolerant Eucalyptus hybrids in some countries, such as Brazil and South Africa $(1,9,33,39,43)$. It is, however, still considered a major constraint to the successful establishment of Eucalyptus

Corresponding author: G. Nakabonge

E-mail: grace.nakabonge@fabi.up.ac.za

Accepted for publication 3 November 2005.

DOI: 10.1094/PD-90-0734

(C) 2006 The American Phytopathological Society plantations and is regarded as a high priority disease.

The genus Chrysoporthe includes two economically important species, Chrysoporthe cubensis (Bruner) Gryzenh. \& M. J. Wingf. and C. austroafricana Gryzenh. \& M. J. Wingf., which are pathogenic to Eucalyptus spp. These species previously were treated in the genus Cryphonectria and, collectively, were known as Cryphonectria cubensis (Bruner) Hodges $(3,12)$. Recognition of Chrysoporthe spp. as distinct from those of the genus Cryphonectria emerged from comparisons of DNA sequence data and clear morphological differences. The most notable morphological differences distinguishing Chrysoporthe from Cryphonectria spp. are the limited stromatic development in the ascostromata, long and black perithecial necks, and black, pyriform, and superficial conidiomata in species of the former genus (12).

Within Chrysoporthe spp., morphological and phylogenetic differences have been observed between isolates from South Africa and those occurring in the in other parts of the world $(12,21)$. Comparisons of DNA sequence data based on multiple gene regions have shown that $C$. cubensis isolates reside in three well-supported phylogenetic groups (21). One of these encompasses South African isolates; an- other includes isolates from Southeast Asia, East Africa, and Australia; and a third group represents isolates from South America, North America, Central Africa, and West Africa (21). Slightly larger asci and rounded ascospores are found in the South African isolates compared with smaller asci and tapered ascospores in isolates occurring in other parts of the world (12). These differences support the treatment of the South African fungus as a distinct species known as $C$. austroafricana (12). Although isolates from Southeast Asia, East Africa, and Australia (Southeast Asian group) group separately from the South American, North American, Central African, and West African (South American group) isolates in phylogenetic comparisons, morphological differences have not been observed between the two groups $(12,21)$. For the present, they are treated collectively as representing C. cubensis $(12,21)$.

C. austroafricana has been reported only from South Africa, where it is considered to be one of the most important pathogens in non-native plantation-grown Eucalyptus spp. $(5,42)$. Before its recognition as a distinct species, this fungus was thought to have been introduced into South Africa (34). Discovery of C. austroafricana on the non-native ornamental tree Tibouchina granulosa Cogn. (20) provided further support for the view that the fungus had been introduced into South Africa. However, the fungus recently has been discovered causing stem and branch cankers on native Syzygium cordatum Hachst. and S. guineense (Willd.) D.C (13). This has given rise to the alternative view that C. austroafricana is native to Africa and has undergone a host jump to non-native Eucalyptus and Tibouchina spp. $(13,30)$. This might then also imply that the fungus would occur in countries neighboring South Africa. Native members of Myrtaceae similar to those in South Africa occur in these countries, as do non-native Eucalyptus spp., which have been used to establish plantations and woodlots for many years.

C. cubensis is known from Africa and several other regions of the world (12). In Africa, the fungus has been reported only from non-native hosts, namely from Eucalyptus spp. in the Republic of Congo $(26,28)$, Democratic Republic of Congo (DRC) (19), and Cameroon (10), as well as 
from S. aromaticum (L.) Merr. \& Perry. (Clove) on Unguja Island, Zanzibar (Tanzania) $(18,22,24)$. It has been hypothesized that this pathogen was introduced to the African continent (12). Its occurrence in West and Central Africa as well as on the eastern seaboard of Africa would suggest that it occurs on non-native plantationgrown Eucalyptus trees in other parts of Africa.

Recently, Roux et al. (27) reported the occurrence of Chrysoporthe spp. from several eastern and southern African countries where Chrysoporthe spp. previously were not known. Their study greatly expanded the known geographic distribution of this genus of canker pathogens in Africa. However, the study by Roux et al. (27) focused only on non-native plantation-grown Eucalyptus spp., and isolates were not identified to species level. The aim of this study was, first, to determine the identity of the isolates collected by Roux et al. (27). A second aim was to conduct additional surveys of native hosts, especially Syzygium spp. in South Africa and other southern and eastern African countries.

\section{MATERIALS AND METHODS}

Collection of isolates. Surveys of indigenous species residing in the order Myrtales growing in the wild as well as non-native Eucalyptus spp. grown in plantations were conducted in Kenya, Malawi, Mozambique, South Africa, Tanzania, and Zambia (Fig. 1). Sampling involved selecting the trees and a subsequent search for disease symptoms. On Syzygium spp., dying branches and stem cankers were the symptoms of interest. On Eucalyptus spp., cracks, cankers on the stems, and swollen bases provided the best indications that Chrysoporthe spp. might be present (Fig. $2 \mathrm{~A}$ and $\mathrm{B})$. After the detection of fruiting structures (Fig. 2C and D), pieces of wood and bark were scraped or cut off from symptomatic trees, placed in brown paper bags, and labeled for subsequent laboratory study and isolation.

Pieces of wood bearing fungal fruiting bodies were placed in moist chambers to induce spore production. Fungal fruiting bodies were identified using standard microscope techniques (12). Isolations were made by lifting spore drops from fruiting structures. Single spore cultures were made by suspending spores (ascospores or conidia) in sterile distilled water. Spore suspensions were spread onto the surface of $2 \%$ malt extract agar (MEA) (malt extract at $20 \mathrm{~g} / \mathrm{liter}$ and agar at $15 \mathrm{~g} / \mathrm{liter}$; Biolab, Midrand, South Africa) containing $100 \mathrm{mg}$ of streptomycin sulfate (SigmaAldrich Chemie GmbH, Steinheim, Germany) in petri dishes. These were incubated overnight and germinating single spores were selected and transferred to fresh plates. Resulting cultures were deposited in the culture collection (CMW) of the Forestry and Agricultural Biotechnology Institute (FABI), University of Pretoria (Table 1), where cultures were preserved on agar slants and sterile distilled water. One isolate from Cameroon that was obtained from the Centraalbureau voor Schimmelcultures (CMW 14852 and CBS 101281) also was included in this study.

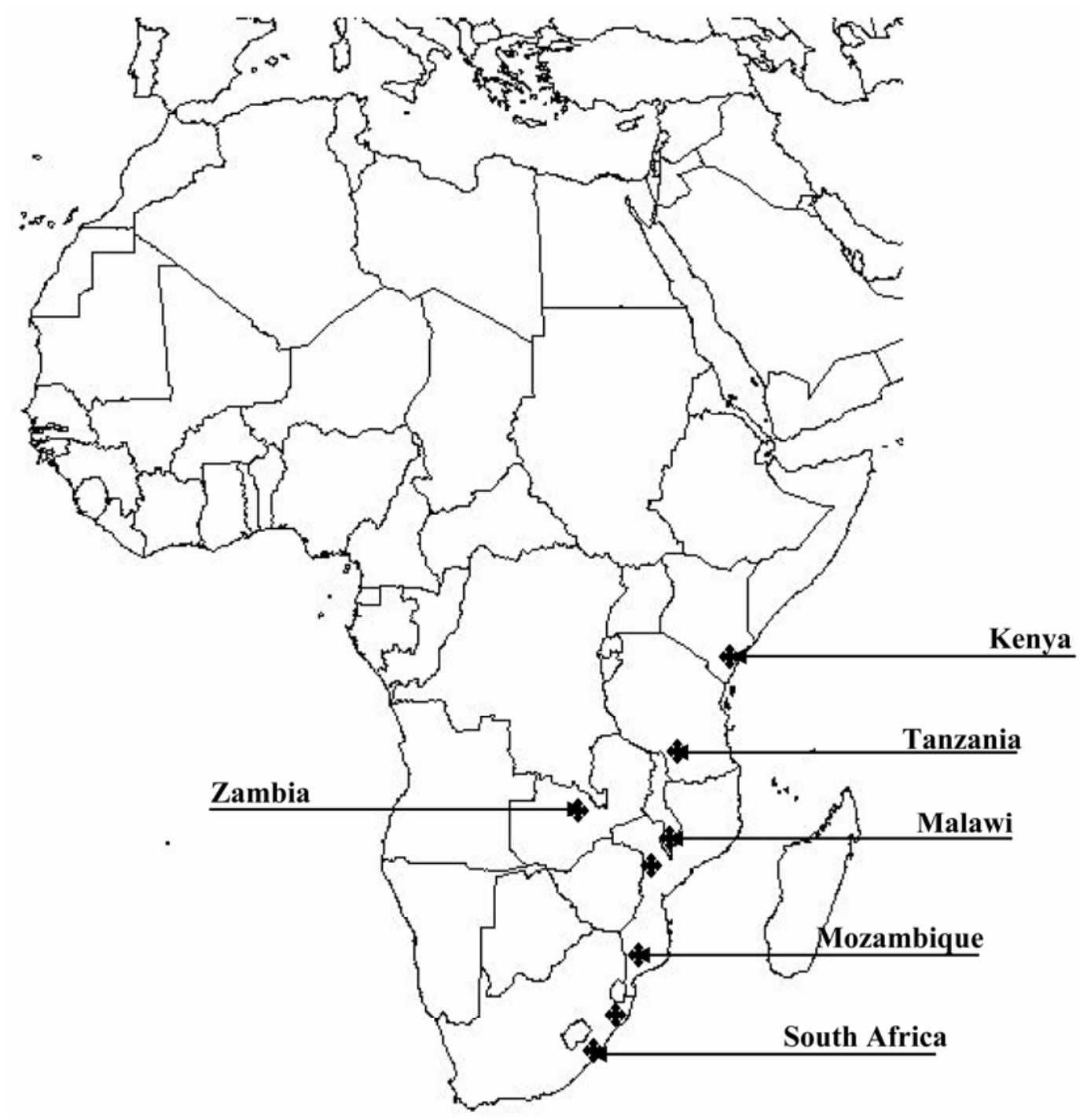

Fig. 1. Map of Africa showing different countries where surveys were conducted. Arrows or crosses indicate general areas within each country where samples were collected. 
DNA sequence comparisons. Representative isolates were selected from each host and geographic area and used for DNA sequence comparisons (Table 1). For each isolate, actively growing mycelium from one MEA plate per isolate was scraped from the surface of the agar using a sterile scalpel and transferred to a $1.5-\mu \mathrm{l}$ Eppendorf tube. Excess liquid was removed from the tubes by centrifugation at $12,000 \mathrm{rpm}$ for $1 \mathrm{~min}$. DNA was extracted using a modification of the protocol described by Gryzenhout et al. (12). DNA concentrations were estimated visually on a $1 \%$ agarose gel using known concentrations of lambda DNA under UV illumination.

The polymerase chain reaction (PCR) was used to amplify $\beta$-tubulin $1, \beta$-tubulin 2 , and rDNA (internal transcribed spacer [ITS] 1, 5.8S and ITS 2) regions $(11,38)$. The reactions were done in a volume of 25 $\mu \mathrm{l}$ comprising $2 \mathrm{ng}$ of DNA template, 800 $\mu \mathrm{M}$ dNTPs, $0.15 \mu \mathrm{M}$ each primer, $5 \mathrm{U} / \mu \mathrm{l}$
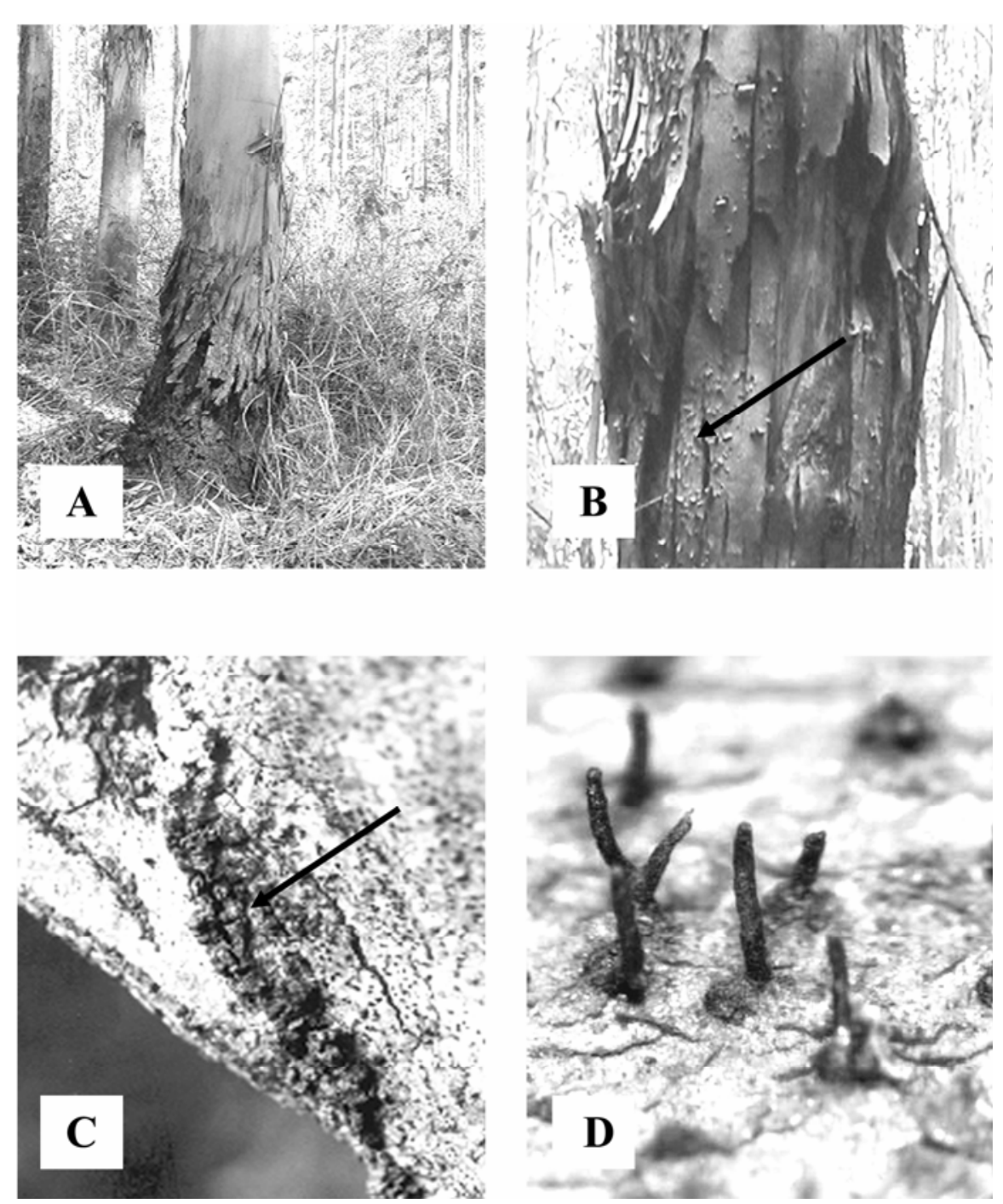

Fig. 2. Signs and symptoms of Chrysoporthe infection on Eucalyptus spp. and Syzygium cordatum. A, Canker caused by Chrysoporthe sp. on Eucalyptus sp. B, Fruiting structures of Chrysoporthe sp. on the bark of Eucalyptus sp. C, Fruiting structures of Chrysoporthe sp. on S. cordatum (figure provided by R. N. Heath, Forestry and Agricultural Biotechnology Institute, University of Pretoria). D, Ascomata of a Chrysoporthe sp.

of Taq polymerase (Roche Diagnostics, Mannheim, Germany), and sterile distilled water $(17.4 \mu \mathrm{l})$. The PCR reactions were carried out on a thermal cycler (Master cycle; Perkin-Elmer Corporation, Wellesley, MA) consisting of an initial denaturation step at $94^{\circ} \mathrm{C}$ for $2 \mathrm{~min}$, followed by 30 amplification cycles consisting of $1 \mathrm{~min}$ at $92^{\circ} \mathrm{C}$ and $30 \mathrm{~s}$ of annealing at 56 to $60^{\circ} \mathrm{C}$, depending on the primer pair used. The ethidium bromide to determine the presence or absence of bands. The PCR products were purified using the High Pure PCR product purification kit according to the manufacturer's protocol (Roche Diagnostics, Mannheim, Germany).

The sequencing reactions $(10 \mu \mathrm{l})$ consisted of $5 \times$ dilution buffer, $4.5 \mu \mathrm{l}$ of $\mathrm{H}_{2} \mathrm{O}$, DNA (50 ng of PCR product), $10 \times$ reaction mix, and one of either reverse or forward primers that were used in the PCR reactions at approximately $2 \mathrm{pmol} / \mu \mathrm{l}$. The PCR
RESULTS

Collection of isolates. Chrysoporthe samples were collected from Kenya, Malawi, Mozambique, South Africa, and Zambia from both non-native Eucalyptus spp. and native Syzygium spp. Eucalyptus spp. had typical symptoms of canker caused by Chrysoporthe spp. Swollen bases and cankers were evident on trees in most of the areas surveyed (Fig. 2). The majority of symptoms on Eucalyptus spp. were characterized by swollen basal cankers (Fig. 2A). However, in one plantation in South Africa and one compartment in Malawi near Mt. Mulanje, cankers were found higher on the tree stems, similar to those observed in South American and Asian countries (Fig. 2B). Symptoms on Syzygium spp. consisted mostly of cankers on dying branches and stems. Both sexual and asexual structures were encountered in all the areas surveyed and on both host genera considered.

In Zambia, most samples collected were from Eucalyptus trees (20 trees) near Kitwe and a few Syzygium trees from Kitwe and Chati. In Mozambique, more than $100 \mathrm{~S}$. cordatum trees were sampled 
over a wide area (Maputo, Gaza, Inhambane, and Sofala provinces), and more than 100 Eucalyptus trees were sampled in the Chimoio and Manica areas. In Kenya, more than 50 Eucalyptus trees were sampled. Although surveys included Eucalyptus spp. in several areas of Kenya, the disease was found only near the coastal town of Malindi. Both Eucalyptus and Syzygium spp. were surveyed in Tanzania (Njombe area), but no Chrysoporthe spp. were obtained from trees in this area. In Malawi, surveys were conducted in several areas, but the disease was found only in the Mt. Mulanje area, on both Eucalyptus grandis and $S$. cordatum. The distribution of Chrysoporthe spp. also was extended in South Africa, with isolates collected from $S$. cordatum in the Port Edward and Umzinto areas. Although other Syzygium spp.,
Heteropyxis spp., and a limited number of Eugenia spp. also were surveyed and sampled in South Africa, no Chrysoporthe spp. were found on these trees.

DNA sequence comparisons. Sequences were obtained for both the ITS rDNA and $\beta$-tubulin 1 and $\beta$-tubulin 2 gene regions. The $\beta$-tubulin regions were approximately $500 \mathrm{bp}$, whereas the ITS rDNA amplified was approximately 558 bp in size. Results of the partition homogeneity test showed that all sequences could be aligned for both regions ( $P$ value $=0.13$ ). The aligned sequences of the combined regions generated 1,439 characters of equal weight, with 1,194 constant characters, of which 101 were parsimony uninformative and 144 were parsimony informative. In all, 100 most parsimonious trees were retained. A consensus tree $(70 \%$ ma- jority rule) with a length of 318 , a consistency index of 0.945 , and retention index of 0.959 , was computed (Fig. 3).

Isolates from Kenya, Malawi, and Mozambique that were collected from Eucalyptus spp. grouped with $C$. cubensis isolates from Southeast Asia and formed a distinct clade ( $96 \%$ bootstrap). Isolates from Eucalyptus and Syzygium spp. from Malawi (CMW17098, 17101, 17110, and 17115), Mozambique (CMW1902, 13929, and 13926) and Zambia (13877 and 13976) grouped with $C$. austroafricana isolates from South Africa, collected from Eucalyptus, Tibouchina, and Syzygium spp. Isolates from the newly sampled areas in South Africa, including those collected from stem cankers from KwaMbonambi (CMW 13878 and 13879), also grouped in this clade (94\% bootstrap). An isolate from

Table 1. Isolates included in this study ${ }^{\mathrm{a}}$

\begin{tabular}{|c|c|c|c|c|c|c|}
\hline Isolate no. & $\begin{array}{l}\text { Alternative } \\
\text { isolate no. }\end{array}$ & Species identity & Host & Origin & Collector & GenBank accession nos. ${ }^{\text {b }}$ \\
\hline CMW 1856 & $\ldots$ & Chrysoporthe cubensis & Eucalyptus sp. & Kauai, Hawaii & NA & AY 083999, AY 084010, AY 084022 \\
\hline CMW 8756 & $\ldots$ & C. cubensis & Syzygium aromaticum & Indonesia & M. J. Wingfield & AF 046896, AF 273077, AF 285165 \\
\hline CMW 3839 & $\ldots$ & C. cubensis & S. aromaticum & Indonesia & M. J. Wingfield & AF 046904, AY 084011, AY 084023 \\
\hline CMW 11288 & CBS 115736 & C. cubensis & Eucalyptus sp. & Indonesia & M. J. Wingfield & AY 214302, AY 214230, AY 214266 \\
\hline CMW 11289 & CBS 115737 & C. cubensis & Eucalyptus sp. & Indonesia & M. J. Wingfield & AY 214303, AY 214231, AY 214267 \\
\hline CMW 10774 & $\ldots$ & C. cubensis & S. aromaticum & Zanzibar & C. S. Hodges & AF 492130, AF 492131, AF 492132 \\
\hline CMW 2631 & $\ldots$ & C. cubensis & E. marginata & Australia & E. Davison & AF 543823, AF543824, AF523825 \\
\hline CMW 10671 & CBS 115752 & C. cubensis & Eucalyptus sp. & Rep. Congo & J. Roux & AF 254219, AF 254221, AF 254223 \\
\hline CMW 10453 & CBS 505.63 & C. cubensis & Eucalyptus sp. & DRC & E. Davison & AY063476, AY063478, AY063480 \\
\hline CMW 10639 & CBS 115747 & C. cubensis & E. grandis & Colombia & C. A. Rodas & AY 263419, AY 263420, AY 263421 \\
\hline CMW 8757 & $\ldots$ & C. cubensis & Eucalyptus sp. & Venezuela & M. J. Wingfield & AF 046897, AF 273069, AF 273464 \\
\hline CMW 10777 & $\ldots$ & C. cubensis & S. aromaticum & Brazil & C. S. Hodges & AY 084005, AY 084017, AY 084029 \\
\hline CMW 10778 & CBS 115755 & C. cubensis & S. aromaticum & Brazil & C. S. Hodges & AY 084006, AY 084018 , AY 084030 \\
\hline CMW 9432 & CBS 115724 & C. cubensis & E. grandis & Mexico & M. J. Wingfield & AY 692321, AY 692324, AY 692323 \\
\hline CMW $13915^{\mathrm{c}}$ & $\ldots$ & C. cubensis & Eucalyptus sp. & Mozambique & G. Nakabonge & DQ246552, DQ246575, DQ246552 \\
\hline CMW $13912^{c}$ & $\ldots$ & C. cubensis & Eucalyptus sp. & Mozambique & G. Nakabonge & DQ246554, DQ246577, DQ246554 \\
\hline CMW $13883^{c}$ & $\ldots$ & C. cubensis & Eucalyptus sp. & Mozambique & G. Nakabonge & DQ246553, DQ246576, DQ246553 \\
\hline CMW $13944^{c}$ & $\ldots$ & C. cubensis & Eucalyptus sp. & Kenya & J. Roux & DQ246550, DQ246573, DQ246550 \\
\hline CMW $13949^{c}$ & $\ldots$ & C. cubensis & Eucalyptus sp. & Kenya & J. Roux & DQ246551, DQ246574, DQ246551 \\
\hline CMW $14774^{c}$ & $\ldots$ & C. cubensis & Eucalyptus sp. & Malawi & J. Roux & DQ246555, DQ246578, DQ246555 \\
\hline CMW $14769^{\circ}$ & $\ldots$ & C. cubensis & Eucalyptus sp. & Malawi & J. Roux & DQ246556, DQ246579, DQ246556 \\
\hline CMW $14852^{c}$ & CBS 101281 & C. cubensis & Eucalyptus sp. & Cameroon & NA & DQ246557, DQ246580, DQ246557 \\
\hline CMW 62 & $\ldots$ & C. austroafricana & E. grandis & South Africa & M. J. Wingfield & AF 292041, AF 273063, AF 273458 \\
\hline CMW $2113^{\mathrm{d}}$ & CBS 112916 & C. austroafricana & E. grandis & South Africa & M. J. Wingfield & AF 046892, AF 273067 , AF 273462 \\
\hline CMW 9327 & CBS 115843 & C. austroafricana & Tibouchina granulosa & South Africa & M. J. Wingfield & AF 273473, AF 273060, AF 273455 \\
\hline CMW 9328 & $\ldots$ & C. austroafricana & T. granulosa & South Africa & M. J. Wingfield & AF 292040, AF 273064, AF 273458 \\
\hline CMW $13902^{c}$ & $\ldots$ & C. austroafricana & S. cordatum & Mozambique & G. Nakabonge & DQ246572, DQ246595, DQ246572 \\
\hline CMW $13926^{c}$ & $\ldots$ & C. austroafricana & S. cordatum & Mozambique & G. Nakabonge & DQ246571, DQ246594, DQ246571 \\
\hline CMW $13929^{c}$ & $\ldots$ & C. austroafricana & Eucalyptus sp & Mozambique & G. Nakabonge & DQ246570, DQ246593, DQ246570 \\
\hline CMW $14561^{\mathrm{c}}$ & $\ldots$ & C. austroafricana & S. cordatum & South Africa & G. Nakabonge & DQ246559, DQ246582, DQ246559 \\
\hline CMW $14562^{\mathrm{c}}$ & $\ldots$ & C. austroafricana & S. cordatum & South Africa & G. Nakabonge & DQ246560, DQ246583, DQ246560 \\
\hline CMW 13878 & $\ldots$ & C. austroafricana & Eucalyptus sp. & South Africa & J. Roux & DQ246566, DQ246589, DQ246566 \\
\hline CMW 13879 & $\ldots$ & C. austroafricana & Eucalyptus sp. & South Africa & J. Roux & DQ246567, DQ246590, DQ246567 \\
\hline CMW $13977^{c}$ & $\ldots$ & C. austroafricana & Eucalyptus sp. & Zambia & J. Roux & DQ246569, DQ246592, DQ246569 \\
\hline CMW $13976^{\mathrm{c}}$ & $\ldots$ & C. austroafricana & S. cordatum & Zambia & J. Roux & DQ246568, DQ246591, DQ246568 \\
\hline CMW $17098^{c}$ & $\ldots$ & C. austroafricana & S. cordatum & Malawi & J. Roux & DQ246561, DQ246584, DQ246561 \\
\hline CMW $17096^{c}$ & $\ldots$ & C. austroafricana & S. cordatum & Malawi & J. Roux & DQ246565, DQ246588, DQ246565 \\
\hline CMW $17101^{\mathrm{c}}$ & $\ldots$ & C. austroafricana & Eucalyptus sp. & Malawi & J. Roux & DQ246562, DQ246585, DQ246562 \\
\hline CMW $17110^{c}$ & $\ldots$ & C. austroafricana & Eucalyptus sp. & Malawi & J. Roux & DQ246563, DQ246586, DQ246563 \\
\hline CMW $17115^{\mathrm{c}}$ & $\ldots$ & C. austroafricana & Eucalyptus sp. & Malawi & J. Roux & DQ246564, DQ246587, DQ246564 \\
\hline CMW 10790 & $\ldots$ & Cryphonectria parasitica & Quercus serrata & Japan & M. Kusunoki & $\mathrm{AF} 140243, \mathrm{AF} 140253, \mathrm{AF} 140255$ \\
\hline CMW 10518 & CBS 112919 & C. nitschkei & Quercus sp. & Japan & T. Kobayashi & AF 452118, AF 525706 , AF 525713 \\
\hline CMW 10463 & CBS 112920 & C. macrospora & Castanopsis cupsidata & Japan & T. Kobayashi & AF 368331, AF 368351, AF 368350 \\
\hline
\end{tabular}

${ }^{a}$ CMW refers to the culture collection of the Forestry and Agricultural Biotechnology Institute (FABI), University of Pretoria, Pretoria, South Africa, and CBS refers to Centraalbureau voor Schimmelcultures, Utrecht, The Netherlands; NA = not available; Rep. Congo $=$ Republic of Congo and DRC $=$ Democratic Republic of Congo.

${ }^{\mathrm{b}}$ GenBank accession numbers are sequence data of the $\beta$-tubulin 1 and 2 (primers Bt1a/1b and Bt2a/2b) and internal transcribed spacer (ITS; primers ITS1 and 4) regions.

${ }^{\mathrm{c}}$ Isolates sequenced in this study.

${ }^{\mathrm{d}}$ Ex-type cultures. 
Cameroon (CMW 14852) that was obtained from the CBS and isolates from DRC and Congo that were included in this analysis grouped together with the South American isolates of C. cubensis (94\% bootstrap).

\section{DISCUSSION}

This study has greatly increased our knowledge of the distribution of two of the most important Eucalyptus pathogens currently known. The geographic range of Chrysoporthe spp. on native Syzygium spp. in eastern and southern Africa also has been expanded considerably. We have shown that $C$. austroafricana causes cankers at the base and higher up on stems of Eucalyptus trees in South Africa and Malawi, which is contrary to prior knowledge. Likewise, the sexual state of this fungus has been shown to be equally as abundant as the asexual state in countries north of
South Africa, contrary to the situation in southern Africa, where the asexual state predominates (34).

C. austroafricana was known previously only from South Africa on non-native Eucalyptus spp. (42), T. granulosa (20), and native $S$. cordatum and $S$. guineense (13). Results of this study have shown that the fungus is also present in Malawi, Mozambique, and Zambia on both non-native Eucalyptus spp. and native S. cordatum. The fungus is widespread in Mozambique and was collected from the southern (Maputo) and central (Chimoio) parts of the country, stretching over a distance of about 1,200 km. Surveys in Zambia were limited to one area and $C$. austroafricana was common on Eucalyptus trees in plantations near the town of Kitwe. On Syzygium sp., the fungus was found in the same area but only on one tree. In Malawi, $C$. austroafricana was collected from one area (Mt. Mulanje) from both Eucalyptus spp. and native $S$. cordatum. The occurrence of $C$. austroafricana in Malawi, Mozambique, and Zambia suggests that the fungus also might be present in other East African countries, such as Tanzania and Zimbabwe.

C. austroafricana recently has been suggested to be native to Africa (13). Our results, showing that the fungus has a wide geographic distribution in southern and eastern Africa on both non-native and native trees, support this hypothesis. This wide distribution and the absence of $C$. austroafricana from other continents, despite extensive surveys, suggests that the fungus is limited to southern Africa. In this respect, it represents a potentially important threat to Myrtaceae elsewhere in the world. The fungus causes a canker disease, which results in reduced growth rates, reduced coppicing, and death of infected

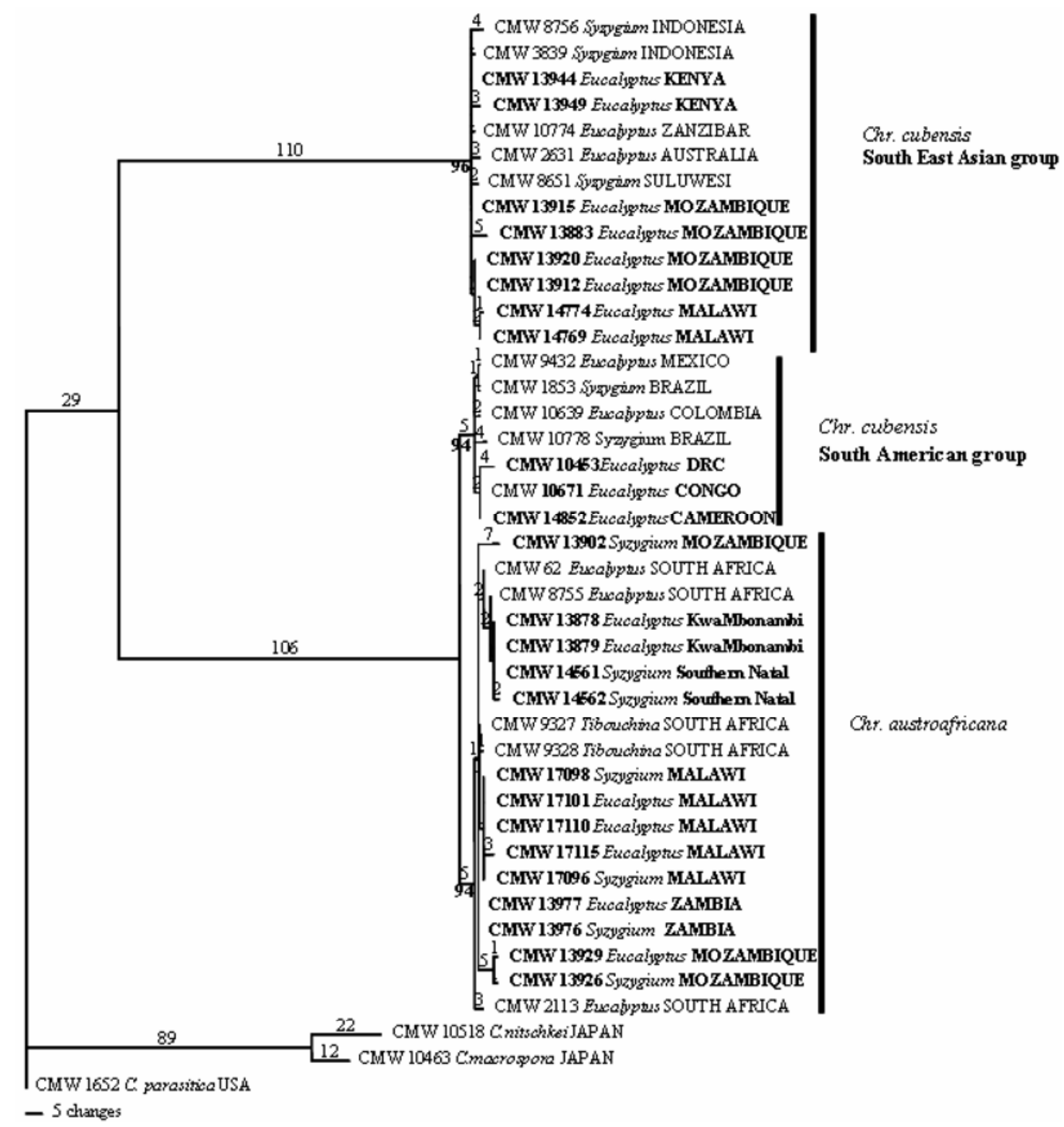

Fig. 3. Phylogenetic tree generated from internal transcribed spacer rDNA and $\beta$-tubulin gene sequence data (tree length $=318$, consistency index $=0.945$, retention index $=0.959$ ) showing relatedness of the isolates of Chrysoporthe spp. collected from African countries. Branch lengths are indicated above the branches and bootstrap values above $50 \%$ are indicated below the branches. Cryphonectria parasitica, C. nitschkei, and C. macrospora were used as outgroups. Isolates collected in this study and isolates included in the study from Republic of Congo, Democratic Republic of Congo (DRC), and Cameroon are in bold. 
Eucalyptus trees (42). On native Syzygium trees, it is found primarily on dead or dying branches (13). Limited studies by Roux et al. (26) and Rodas et al. (25) have shown that $C$. austroafricana isolates from South Africa are more virulent than $C$. cubensis isolates. Therefore, the introduction of $C$. austroafricana isolates to other continents could have serious negative impacts on commercial forestry and biodiversity.

It initially was believed that C. austroafricana causes only basal cankers on the stems of Eucalyptus spp. in South Africa, whereas $C$. cubensis gives rise to both basal cankers and cankers higher up on the stems of trees in Southeast Asia and South America $(5,34,42,40)$. During the course of our surveys, C. austroafricana was isolated from cankers up to $3 \mathrm{~m}$ above ground level on Eucalyptus trees in the KwaZulu/Natal province (KwaMbonambi) in South Africa and in Malawi. This symptom clearly is less common than it is with C. cubensis elsewhere in the world. It is highly possible that environmental factors have an influence on areas of infection on the stems.

One of the early indications that C. austroafricana and C. cubensis might represent different fungi was the fact that cankers of the former fungus typically are covered with asexual structures (pycnidia), whereas those of the latter fungus more typically bear sexual perithecia $(34,41,42)$. During the present surveys, both sexual and asexual structures of $C$. austroafricana commonly were found on Eucalyptus spp. as well as on native Syzygium spp. in Malawi, Mozambique, and Zambia. In South Africa, the sexual state of this fungus is abundant on native Syzygium spp. but not on Eucalyptus (13). Thus, this characteristic might be associated with environmental factors such as temperature and humidity, which are lower in South Africa than more northern African countries.

C. cubensis has been known in Africa since the early $1960 \mathrm{~s}$, where it has been recorded on Eucalyptus spp. and S. aromaticum $(10,19,22)$. Our surveys have extended the geographic range of the fungus to include Kenya, Malawi, and Mozambique, where it occurs on Eucalyptus spp. Phylogenetic analyses showed that $C$. cubensis from Kenya, Mozambique, and Malawi groups in the same subclade as $C$. cubensis from Tanzania and Southeast Asia, but separate from isolates from South America, the Republic of Congo, DRC, and Cameroon. This suggests that East African isolates could have been introduced from Asia. This finding should now be tested at the population biology level. It might raise clues as to how the pathogen has moved around the world and provide knowledge that will reduce the risks of future introductions into new areas.

The question regarding the origin of $C$. cubensis remains to be resolved. A previ- ous view has been that the fungus originated in Indonesia on native $S$. aromaticum (18). An alternative hypothesis has been that the fungus originated on native plants in South America $(40,41)$. There have been more recent reports of $C$. cubensis from native plants in South America (25), adding support to the view that this area could represent the origin of the fungus. Population biology studies using vegetative compatibility groups (VCGs) on C. cubensis isolates from South America (Venezuela and Brazil) and Southeast Asia (Indonesia) have shown that a large number of VCGs occur in each country $(36,37)$. This suggests either a high level of outcrossing within the populations or well-established native populations in both areas. The fact that the Indonesian population is also highly diverse, together with the clear phylogenetic distinction between Asian and South American isolates, supports suggestions that these two groups of $C$. cubensis isolates might represent distinct species $(12,21)$.

The results of this study, combined with previous findings $(18,19,22,27,28,42)$, show that Chrysoporthe spp. have a wide distribution in Africa. In East Africa, all isolates of $C$. cubensis collected reside in the Southeast Asian group defined for the fungus. In contrast, all isolates from West and Central Africa reside in the South American clade of C. cubensis. In Mozambique, South Africa, and Zambia, only C. austroafricana is present. The populations of isolates collected in the surveys presented in this study will make it possible to consider the origin of Chrysoporthe spp. on the African continent and to better understand how these fungi are moving within the region.

The knowledge generated in this study is important to Eucalyptus plantation managers. For example, disease caused by $C$. austroafricana in South Africa is managed largely through the planting of diseasetolerant clones $(33,35)$. However, our study shows that, within $2,000 \mathrm{~km}, C$. cubensis also occurs, and this is a pathogen against which South African Eucalyptus stock has not been tested. Thus, future outbreaks of canker caused by Chrysoporthe spp. in South Africa should be carefully monitored. Countries in Central and West Africa, Asia, Australia, and South America, where C. austroafricana is still unknown, should also take note of the potential threat of the fungus in their areas.

\section{ACKNOWLEDGMENTS}

We acknowledge financial support provided by members of the Tree Protection Cooperative Programme (TPCP); the THRIP initiative of the Department of Trade and Industry; the DST/NRF Centre of Excellence in Tree Health Biotechnology, South Africa; Third World Organisation for Women in Science (TWOWS), Makerere University, Uganda; and the British Society for Plant Pathology (BSPP). We thank the following persons and institutions or organizations in the different countries for assistance during sampling: L. Mwangi of the
Kenyan Forestry Research Institute (KEFRI); W. Sagona of the Malawian Forestry Research Institute (FRIM); A. Mbaga of Tanganyika Wattle Company, Njombe; C. Nguvulu of Zambian Forestry Research Institute; E. da Cruz and I. F. Maluleque of Centro de Experimentação Florestal, Mozambique; and P. Swanepoel of Ifloma, Mozambique.

\section{LITERATURE CITED}

1. Alfenas, A. C., Jeng, R., and Hubbes, M. 1983. Virulence of Cryphonectria cubensis on Eucalyptus species differing in resistance. Eur. J. For. Pathol. 13:197-205.

2. Boerboom, J. H. A., and Maas, P. W. T. 1970. Canker of Eucalyptus grandis and E. saligna in Surinam caused by Endothia havanensis. Turrialba 20:94-99.

3. Bruner, S. C. 1917. Una enfermedad gangrenosa de los eucaliptos. Estacion Exp. Agron. Bull. 37:1-33.

4. Conradie, E., Swart, W. J., and Wingfield, M. J. 1990. Cryphonectria canker of Eucalyptus an important disease in plantation forestry in South Africa. S. Afr. For. J. 152:43-49.

5. Conradie, E., Swart, W. J., and Wingfield, M. J. 1992. Susceptibility of Eucalyptus grandis to Cryphonectria cubensis. Eur. J. For. Pathol. 22:312-315.

6. Davison, E. M., and Coates, D. J. 1991. Identification of Cryphonectria cubensis and Endothia gyrosa from eucalypts in Western Australia using isozyme analysis. Aust. Plant Pathol. 20:157-160.

7. Felsenstein, J. 1985. Confidence intervals on phylogenetics: an approach using bootstrap. Evolution 39:783-791.

8. Florence, E. J. M., Sharma, J. K., and Mohanan, C. 1986. A stem canker disease of Eucalyptus caused by Cryphonectria cubensis in Kerala. Kerala For. Res. Inst. Sci. Pap. No. 66:384-387.

9. Gadgil, P. D., Wardlaw, F. A., Sharma, J. K., Dick, M. A., and Wingfield, M. J. 2000. Management of diseases in eucalypt plantations. Pages 519-529 in: Diseases and Pathogens of Eucalypts. CSIRO Publishing, Collingwood, Australia.

10. Gibson, I. A. S. 1981. A canker disease of Eucalyptus new to Africa. FAO For. Genet. Res. Inf. 10:23-24.

11. Glass, N. L., and Donaldson, G. C. 1995. Development of primer sets designed for use with the PCR to amplify conserved genes from filamentous ascomycetes. Appl. Environ. Microbiol. 61:1323-1330.

12. Gryzenhout, M., Myburg, H., Van der Merwe, N. A., Wingfield, B. D., and Wingfield, M. J. 2004. Chrysoporthe, a new genus to accommodate Cryphonectria cubensis. Stud. Mycol. 50:119-142.

13. Heath, R. N., Gryzenhout, M., Roux, J., and Wingfield, M. J. Discovery of Chrysoporthe cubensis on native Syzygium species in South Africa. Plant Dis. 90:433-438.

14. Heulsenbeck, J. P., Bull, J. J., and Cunningham, C. W. 1996. Combining data in phylogenetic analysis. Tree 11:152-158.

15. Hodges, C. S., Geary, T. F., and Cordell, C. E. 1979. The occurrence of Diaporthe cubensis on Eucalyptus in Florida, Hawaii and Puerto Rico. Plant Dis. 63:216-220.

16. Hodges, C. S., Reis, M. S., Ferreira, F. A., and Henfling, J. D. M. 1976. O cancro do eucalipto causado por Diaporthe cubensis. Fitopatol. Bras. 1:129-170.

17. Hodges C. S. 1980. The taxonomy of the Diaporthe cubensis. Mycologia 72:542-548.

18. Hodges, C. S., Alfenas, A. C., and Cordell, C. E. 1986. The conspecificity of Cryphonectria cubensis and Endothia eugeniae. Mycologia 78:343-350.

19. Micales, J. A., Stipes, R. J., and Bonde, M. R. 1987. On the conspecificity of Endothia eugeniae and Cryphonectria cubensis. My- 
cologia 79:707-720.

20. Myburg, H., Gryzenhout, M., Heath, R., Roux, J., Wingfield, B. D., and Wingfield, M. J. 2002b. Cryphonectria canker on Tibouchina in South Africa. Mycol. Res. 106:1299-1306.

21. Myburg, H., Gryzenhout, M., Wingfield, B. D., and Wingfield, M. J. 2002. $\beta$-tubulin and Histone $\mathrm{H} 3$ gene sequences distinguish Cryphonectria cubensis from South Africa, Asia and South America. Can. J. Bot. 80:590-596.

22. Myburg, H., Gryzenhout, M., Wingfield, B. D., and Wingfield, M. J. 2003. Conspecificity of Endothia eugeniae and Cryphonectria cubensis: A re-evaluation based on morphology and DNA sequence data. Mycoscience 104:187-196.

23. Myburg, H., Wingfield, B. D., and Wingfield, M. J. 1999. Phylogeny of Cryphonectria cubensis and allied species inferred from DNA analysis. Mycologia 91:243-250.

24. Nutman, F. J., and Roberts, F. M. 1952. Acute dieback of clove trees in the Zanzibar Protectorate. Ann. Appl. Biol. 39:599-608.

25. Rodas, C. A., Gryzenhout, M., Myburg, H., Wingfield, B. D., and Wingfield, M. J. 2005. Discovery of the Eucalyptus canker pathogen Chrysoporthe cubensis on native Miconia (Melastomataceae) in Colombia. Plant Pathol. 54:460-470.

26. Roux, J., Coutinho, T. A., Wingfield, M. J., and Bouillet, J. P. 2000. Diseases of plantation Eucalyptus in the Republic of the Congo. S. Afr. J. Sci. 96:454-456.

27. Roux, J., Meke, G., Kanyi, B., Mwangi, L., Mbaga, A., Hunter, G. C., Nakabonge, G., Heath, R. N., and Wingfield, M. J. Diseases of plantation forestry tree species in Eastern and Southern Africa. S. Afr. J. Sci. 101:409-413.
28. Roux, J., Myburg, H., Wingfield, B. D., and Wingfield, M. J. 2003. Biological and phylogenetic analysis suggest that two Cryphonectria species cause cankers of Eucalyptus in Africa. Plant Dis. 87:1329-1332.

29. Sharma, J. K., Mohanan, C., and Florence, E. J. M. 1985. Occurrence of Cryphonectria canker disease of Eucalyptus in Kerala, India. Ann. Appl. Biol. 106:265-276.

30. Slippers, B., Stenlid, J., and Wingfield M. J. 2005. Emerging pathogens: fungal host jumps following anthropogenic introduction. Tree 20:420-421

31. Swofford, D. L. 1998. PAUP*. Phylogenetic analysis using parsimony (*and other methods). Version 4. Sinauer Associates, Sunderland, MA.

32. Van der Merwe, N. A., Myburg, H., Wingfield, B. D., Rodas, C., and Wingfield M. J. 2001. Identification of Cryphonectria cubensis from Colombia based on rDNA sequence data. S. Afr. J. Sci. 97:295-297.

33. Van Heerden, S. W., Amerson, H. V., Preisig, O., Wingfield, B. D., and Wingfield, M. J. 2005. Relative pathogenicity of Cryphonectria cubensis on Eucalyptus clones differing in their resistance to $C$. cubensis. Plant Dis. 89:659-662.

34. Van Heerden, S. W., and Wingfield M. J. 2001. Genetic diversity of Cryphonectria cubensis isolates in South Africa. Mycol. Res. 105:94-99.

35. Van Heerden, S. W., and Wingfield M. J. 2002. Effect of environment on the response of Eucalyptus clones to inoculation with Cryphonectria cubensis. For. Pathol. 32:395-402.

36. Van Heerden, S. W., Wingfield M. J., Couthino T., Van Zyl, L. M., and Wright, J. A 1997. Di- versity of Cryphonectria cubensis isolates in Venezuela and Indonesia. Pages 142-146 in: Proc. IUFRO Conf. Silvicult. Improv. Eucalypts. Salvador, Brazil.

37. Van Zyl, L. M., Wingfield, M. J., Alfenas, C. A., and Crous, P. W. 1998. Population diversity among Brazilian isolates of Cryphonectria cubensis. For. Ecol. Manage. 112:41-47.

38. White, T. J., Bruns, T., Lee, S., and Taylor, J. 1990. Amplification and direct sequencing of fungal ribosomal RNA genes for phylogenetics. Pages 315-322 in: PCR Protocols: A Guide to Methods and Applications. Academic Press, San Diego, CA.

39. Wingfield, M. J. 1990. Current status and future prospects of forest pathology in South Africa. S. Afr. J. Sci. 86:60-62.

40. Wingfield, M. J. 2003. Daniel McAlpine Memorial Lecture. Increasing threat of diseases to non-native plantation forests in the Southern Hemisphere: lessons from Cryphonectria canker. Aust. Plant Pathol. 23:133-139.

41. Wingfield, M. J., Rodas, C., Myburg, H. Venter, M., Wright, J., and Wingfield, B. D. 2001. Cryphonectria canker on Tibouchina in Colombia. For. Pathol. 31:297-306.

42. Wingfield, M. J., Swart, W. J., and Abear, B. J. 1989. First record of Cryphonectria canker of Eucalyptus in South Africa. Phytophylactica 21:311-313

43. Wingfield, M. J., Swart, W. J., and Kemp, G. H. J. 1991. Pathology considerations in clonal propagation of Eucalyptus with special reference to the South African situation. Pages 881820 in: Proc. IUFRO Symp. Intensive Forestry: The Role of Eucalypts. South African Institute of Forestry, Pretoria, South Africa. 